\title{
Selection and recommend of quinoa (Chenopodium quinoa) genotypes based on the yield genotypic adaptability and stability ${ }^{1}$
}

\author{
Edmar Soares de Vasconcelos ${ }^{2 *} \mathbb{D}$, Marcia de Moraes Echer ${ }^{2}$, Marcio André Kliemann ${ }^{2}$, Marcelo Júnior Lang ${ }^{2}$
}

10.1590/0034-737X201966020006

\begin{abstract}
The present study aimed to select and recommend quinoa genotypes based on the yield genotypic adaptability and stability, by the method of the Harmonic mean of relative performance of genotypic values. Five experiments were conducted during the crop seasons of 2014 and 2015 in two locations in the Western region of Paraná State, Brazil. This study involved the evaluation of the yield of thirteen quinoa genotypes. Initially, the genotypic values (GV) were obtained by employing BLUP/REML methodology for mixed models. After, the values of the harmonic mean for genotypic value $(\mathrm{HMGV} * \mathrm{MG})$, the relative performance for genotypic values $\left(\mathrm{RPGV}^{*} \mathrm{MG}\right)$ and the harmonic mean of the relative performance for genotypic values (HMRPGV*MG) were obtained. The genotypes Q1317 and Q2014 were the best indicated for cultivation in the summer crop, with medium yield genotypic stability and adaptability. The genotype Q1318 is recommended for winter crop, presenting high yield genotypic stability and adaptability.
\end{abstract}

Keywords: Chenopodium quinoa; genotypic value; BLUP/REML; mixed model.

\section{INTRODUCTION}

Quinoa (Chenopodium quinoa Willd) is known and used on large scale by farmers in Colombia, Ecuador, Peru, Bolivia, Chile and Argentina. Quinoa is increasingly cultivated in the world by being present, cultivated or under experimentation, in more than 95 countries around the world (Bazile et al., 2016). In 2017, the global quinoa production volume amounted to about 146.74 thousand metric tons. The amount produced in Brazil is considered insignificant for the world statistics, being only related to the researches of Embrapa, University of Brasília (UnB) or Universidade Estadual do Oeste do Paraná (UNIOESTE) (Spehar et al., 2011; Vasconcelos et al., 2013).

In Brazil there are studies related to the cultivation of quinoa in the Brazilian savannah region (Spehar et al., 2011) and in tropical conditions (Vasconcelos et al., 2013). However, even within one of these environmental conditions there is great variability generating a differentiated response of each genotype (Tardieu, 2013), requiring studies involving more than one growing environment to guarantee efficiency of genotype selection. These studies are known as assessability of yield adaptability and stability.

Studies of yield adaptability and stability are carried out in different crops as soybean (Vasconcelos et al., 2010), corn (Oliveira et al., 2017), cowpea (Torres et al., 2015), pop corn (Freitas et al., 2013), jatropha (Rodrigues et al., 2017), eucalyptus (Pupin et al., 2015), white oat (Hawerroth et al., 2013), rice (Colombari Filho et al., 2013), carrot (Silva et al., 2011), quinoa (Ali et al., 2018), among others. However, there is no available research about the yield adaptability and stability of quinoa in Brazil.

For analysis of the yield adaptability and stability there are several methods, standing out: Lin and Binns method, Eberhart and Russell (Eberhart \& Russell 1966); Cruz, Torres and Vencovsky (Cruz et al., 1989), Integrated method (Vasconcelos et al., 2011), AMMI - Additive Main effects and Multiplicative Interaction model (Gauch, 2006). Another method based on mixed models, that has often been employed with this type of analysis, is the HMRPGV

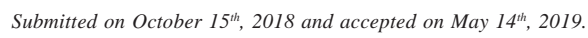

${ }^{1}$ This paper is part of the research report sent to the Fundação Araucária.

${ }^{2}$ Universidade Estadual do Oeste do Paraná, Departamento de Agronomia, Marechal Cândido Rondon, Paraná, Brazil. edmar.vasconcelos@unioeste.br; mmecher@bol.com.br; mkliemann@nideraseeds.com; mlang@unioeste.br

*Corresponding author: edmar.vasconcelos@unioeste.br 
- harmonic mean relative performance of genotypic values (Resende, 2007).

The method of the Harmonic mean of relative performance of genotypic values has generated excellent results for stability and adaptability studies (Oliveira et al., 2017; Torres Filho et al., 2017; Rodrigues et al., 2017; Costa et al., 2015; Almeida Filho et al., 2014). The advantages of this procedure include the adaptability and stability, simultaneously, selection for productivity. With this method, we are working with unbalanced data and no variance homogeneity (Colombari Filho et al., 2013). Consequently, the use of HMRPGV in data from quinoa trials can generate information of great importance for the selection of genotypes with yield stability and adaptability.

Therefore, the present paper aimed to select and recommend quinoa genotypes based on the yield genotypic adaptability and stability, by the method of the Harmonic mean of relative performance of genotypic values.

\section{MATERIAL AND METHODS}

Was conduct five experiments during the crop seasons of 2014 and 2015 in two locations in the Paraná State, in the municipalities of Entre Rios do Oeste and for mixed modelsthe yield (ton.RVG and MHPRVG.Marechal Cândido Rondon (Table 1). In this region, the average annual temperature is $23^{\circ} \mathrm{C}$, with variation between 1,600 and 1,800 $\mathrm{mm}$ of the total annual precipitation. The soil is classified as Eutroferric Red Latosol with clay texture.

The experiments were arranged in a randomized complete block design, with 3 replications. The study involved thirteen quinoa genotypes: Q2014, Q1301, Q1302, Q1303, Q1304, Q1306, Q1310, Q1317, Q1318, Q1320, Q1321, Q1324 and Q1331. Line spacing was of $0.5 \mathrm{~m}$ each, arranged in five rows on the experimental plot, which has 5.5 meters of length. The experimental plot useful area was composed by the three central lines with 4.5 meters of length, totaling $6.75 \mathrm{~m}^{2}$.

The fertilization was $280 \mathrm{~kg} \mathrm{ha}^{-1}$ of the formulated 08-20-20 in conventional crops and $400 \mathrm{~kg} \mathrm{ha}^{-1}$ of pelleted organic fertilizer in the formulation $05-08-08$ with addition of organic matter (environment 3). The distribution of the fertilizers was carried out in lines with the aid of a Semeato sowing plantation, model SDM1517, drawn by a tractor TL $754 \times 4$ aspirated with $78 \mathrm{cv}$. Seeding was done manually using the lines left by the sowing plantation. In the seeding process, 45 seeds per linear meter were arranged, with thinning to guarantee only 40 plants per square meter.

The culture treatments were carried out whenever necessary in order to ensure that there was no competition between quinoa plants and weeds and also to avoid excessive attack from pests and diseases in the crop.

Harvesting, thrash and cleaning of the quinoa seeds was done manually with approximately 100 days after emergence of the seedlings (varying according to genotype), after that the seeds were dried in the sun until reaching $13 \%$ moisture. Then, the mass of the harvested seeds was determined by the balance with the precision of $0.005 \mathrm{~g}$, obtaining the values in $\mathrm{kg}$, these values extrapolated to yield in $\mathrm{kg} \mathrm{ha}^{-1}$.

The model below is in a linear form:

$y=X_{r}+Z_{g}+W_{b}+T_{g a}+e$

Where:

$y$ is the data vector or vector of the observations; $r$ is the vector of the replications effects (assumed as fixed and adjust block-environments combinations) added to the general mean; $g$ is the vector of the genotypic effects (assumed as random); b is the vector of blocks (effects random); ga is the vector of effects of genotypes $\mathrm{x}$ environments interaction (random), and, e is the vector of errors or residuals (random). Capital letters represent the incidence matrixes for these effects. The effects of the crop season and municipalities are grouped into effect a, as they are environmental effects (effects random) (Resende, 2007).

The effects significance of the model was estimated by an analysis of deviance, as recommended by Resende (2002). The effect block within the environments was tested by $\mathrm{F}$ test at $5 \%$ of error probability.

Table 1: Environmental descriptions of site, year and crop seasons, as well as the seeding system used

\begin{tabular}{lcccccc}
\hline Environment & Municipalities & Latitude & Longitude & Altitude & Year / Crop season & Seeding system \\
\hline 1 & Marechal Cândido Rondon & -24.5321 & -54.0176 & 422 & $2014 /$ Winter & conventional $^{1}$ \\
2 & Entre Rios do Oeste & -24.6813 & -54.2854 & 267 & $2014 / 15 /$ Summer & no-tillage $^{2}$ \\
3 & Entre Rios do Oeste & -24.6757 & -54.2817 & 260 & $2014 / 15 /$ Summer & conventional organic $^{3}$ \\
4 & Marechal Cândido Rondon & -24.5316 & -54.0176 & 421 & $2014 / 15 /$ Summer & conventional $^{2}$ \\
5 & Entre Rios do Oeste & -24.6810 & -54.2823 & 265 & $2015 /$ Winter & no-tillage \\
\hline
\end{tabular}

${ }^{1}$ Seeding system with soil tillage and use of chemical fertilizer, herbicides and insecticides when necessary; ${ }^{2}$ Seeding system without soil tillage, desiccation of area with herbicide, use of chemical fertilizer, herbicides and insecticides when necessary; ${ }^{3}$ Seeding system with soil tillage and use of organic fertilizer, without use of herbicides and insecticides. 
By using empirical BLUP predictors (REML/BLUP) with this model in matrix, it was possible to obtain estimates of mean effect for environment $\mathrm{j}\left(\hat{\mu}_{j}\right)$, genotypic effects for genotype $\mathrm{i}\left(\hat{g}_{i}\right)$ and effects of the genotypes x environments interaction $\left(g \widehat{e_{i j}}\right)$ involving the genotype $\mathrm{i}$ and the environment $\mathrm{j}$. After that the genetic values $\left(G V_{i j}\right)$ effects was obtained for genotype $i$ and environment $\mathrm{j}$, as follows:

$G V_{i j}=\hat{\mu}_{j}+\hat{g}_{i}+g \widehat{e_{i j}}$

With the $G V_{i j}$ data, the Tocher test was performed as presented by Cruz et al. (2014) within each growth condition.

With the data of $G V_{i j}$ that were obtained for all genotypes, the values of the harmonic mean for genotypic value (HMGV) as a measure of stability, the relative performance for genotypic values (RPGV) as a measure of adaptability and the harmonic mean of the relative performance for genotypic values (HMRPGV) as a measure of stability, adaptability and productivity, simultaneously. These data were obtained in accordance with the expressions:

$$
\begin{aligned}
& H M G V_{i}=\frac{1}{\sum_{j=1}^{l} \frac{1}{G V_{i j}}} \\
& R P G V_{i} * M G=\frac{1}{l}\left(\frac{\sum_{j=1}^{l} V G_{i j}}{M_{j}}\right) * M G \\
& H M R P G V_{i} * M G=\frac{1}{\sum_{j=1}^{l} \frac{1}{R P G V_{i j}}} * M G
\end{aligned}
$$

Where:

$l$ is the number of environments; $G V_{i j}$ is the genotypic value of the genotype $i$ in the environment $j$; and, $M G$ is the general mean.

With the $H M G V_{i}, R P G V_{i}$ and $H M R P G V_{i}$ datas, the Tocher test was performed as presented by Cruz et al. (2014). This is possible because the Tocher test allows to group similar behaviors of the genotypes, this way in the processes of group formation, the distances within the group are smaller than the distances between the groups. Thus, we will have values of $H M G V_{i}, R P G V_{i}$ and $H M R P G V_{i}$, smaller within the groups formed than the distances between the groups. With this, we facilitate the discussion of the results of $H M G V_{i}, R P G V_{i}$ and $H M R P G V_{i}$, since we can distinguish the behavior of each genotype.

The Selegen software system (Resende 2016) was used for the analyses, except for Tocher test, this was done by the use of GENES (Cruz, 2013).

\section{RESULTS AND DISCUSSION}

The genotypes $\mathrm{x}$ environments interaction $(\mathrm{G} \times \mathrm{E})$ was significant $(p<0.01)$ by the analyses of deviance (Table 2), indicating that there is differentiated behavior of the genotypes when evaluated in different environments. This significance can be connected to the condition of quinoa being alotetraploid (Zurita-Silva et al., 2014), due to possesses four gene pools the quinoa can present a differentiated response in several environments. For to show this it is enough to imagine that, the segregation of a single gene from a heterozygous alotetraploid genotype can generate five different genotypes (AAAA, AAAa, AAaa, Aaaa and aaaa), whereas in the diploid we will have only three different genotypes (AA, Aa and aa). In this case, if the genotype with recessive alleles has less adaptive potential than the others, we will have $1 / 3$ of the plants with this condition in diploids and $1 / 5$ in tetraploids. Considering this condition we would have a greater adaptive power in the tetraploids.

The genotypes effects was not significant $(\mathrm{p} \leq 0.05)$ by the analyses of deviance (Table 2). This result may be related to the condition that the genotypes still have variability, because it comes from plant selection, followed by advancement of generations, thus guaranteeing that their general average productivity (average of replicates and cultivation environments) do not present differences. Thus, we can show that the effects of interaction $\mathrm{G} x \mathrm{E}$ are the main responsible for the significance of the model. Also, the differentiated behavior of the genotypes in the different environmental conditions of the cultures were responsible for the observed differences, as already evidenced by Spehar \& Rocha (2010).

The component of variation of the $\mathrm{G} \times \mathrm{E}$ interaction and the coefficient of determination for this source of the variation were significant by the test $\mathrm{t}(\mathrm{p}<0.05)$ (Table 2$)$. With this result we can state that the genetic difference between the genotypes was presented when they were submitted to the environments used in this research, and despite of the fact that the environments have potential for differentiation of the genotypes behavior under analysis, according to Oliveira et al. (2017). It is also worth mentioning that $\mathrm{G} \times \mathrm{E}$ interaction hinder the selection of stable and satisfactory genotypes for a particular trait (Cruz et al., 2014).

The genotypes Q1317 and Q1321 form the group a, with the highest genotypic value when cultivated in Entre Rios do Oeste, achieve a genotypic value of 1988.02 and $1968.61 \mathrm{~kg} \mathrm{ha}^{-1}$, respectively. In Marechal Cândido Rondon, the genotypes Q2014 and Q1306 will constitute the group a, with the highest genotypic values when cultivated in the summer crop of 2014/15. These genotypes reached genotypic values of 1975.87 and $2027.13 \mathrm{~kg} \mathrm{ha}^{-1}$, respectively (Table 3 ). When considering the results for both environments in the crop summer, we found that the genotypes Q2014, Q1306 and Q1321 have the genotypic value near or above $1750 \mathrm{~kg} \mathrm{ha}^{-1}$. 
The genotype Q2014, which is the union of the seeds of all the other genotypes, presented a productive behavior superior to the general average when cultivated in the crop summer. It is evident that this genotype has high adaptive capacity for cultivation in conditions with temperature higher than the average in which the genotypes were evaluated.

The genotypes Q1318 and Q1320 when cultivated in the winter season in Entre Rios do Oeste formed the group a with the highest genotypic values. These presented genotypic values of 466.34 and $429.79 \mathrm{~kg} \mathrm{ha}^{-1}$, respectively. In Marechal Cândido Rondon the genotypes Q1304 and Q1324 formed the group a, with the highest genotypic values, achieve 450.44 and $486.98 \mathrm{~kg} \mathrm{ha}^{-1}$, respectively (Table 3).

The cultivation of quinoa genotypes in the summer and winter crop showed that genotype selection should be performed for each cultivated period or crop season.

Table 2: Results of deviance analyze, components of variance and determination of coefficients for to the joint analysis of the thirteen quinoa genotypes in five environments, in Marechal Cândido Rondon and Entre Rios do Oeste - Paraná, Brazil

\begin{tabular}{lcccc}
\hline Effect & Deviance $^{1}$ & LRT $\left(\div{ }^{2}\right)^{2}$ & Component of Variance $^{\text {Coeficient of determination }}$ \\
\hline Genotypes & 2077.03 & $0.01^{\mathrm{NS}}$ & $156.6970^{\mathrm{NS}}$ & $0.0026^{\mathrm{NS}}$ \\
Genotypes x Environments & 2121.81 & $44.79^{* *}$ & $30995.4645^{+}$ & $0.5080^{+}$ \\
Residue & - & - & 25533.9046 & 0.4185 \\
Complete Model & 2077.02 & - & 61017.3124 & 1.0000 \\
Block/Environments & 2085.34 & $\mathrm{~F}=8.32^{* *}$ & $4331.2463^{\mathrm{NS}}$ & $0.0710^{\mathrm{NS}}$ \\
\hline
\end{tabular}

${ }^{1}$ Deviance of the adjusted model without the corresponding effects; ${ }^{2}$ Likelihood Ratio for models with and without the respective effect. $*$ and $* *$ Significant by the chi-square test at $5 \%$ (3.84) and 1\% (6.63), respectively. ${ }^{+}$Significant by the $\mathrm{t}$ test $(\mathrm{p}<0.05)$.

Table 3: Predicted genotypic values (GV) to the yield trait of thirteen quinoa genotypes evaluated in five environments, for 2014 and 2015 agricultural years, in Marechal Cândido Rondon (MCR) and Entre Rios do Oeste (ERO) - Paraná, Brazil

\begin{tabular}{|c|c|c|c|c|}
\hline \multirow{2}{*}{ Location } & \multirow{2}{*}{ Genotype } & \multirow{2}{*}{$\frac{\text { Summer Crop }}{\mathbf{G V}^{4}}$} & \multirow{2}{*}{$\frac{\text { Winter Crop }}{\mathbf{G V}^{4}}$} & \multirow{2}{*}{$\frac{\text { Organic Summer Crop }}{\mathbf{G V}^{4}}$} \\
\hline & & & & \\
\hline \multirow[t]{13}{*}{$\mathrm{ERO}^{2}$} & Q2014 & $1833.73 \mathrm{~b}$ & - & $182.91 \mathrm{~b}$ \\
\hline & Q1301 & $1592.14 \mathrm{c}$ & $301.62 \mathrm{c}$ & $111.45 \mathrm{c}$ \\
\hline & Q1302 & $1476.06 \mathrm{~d}$ & $342.36 \mathrm{~b}$ & $169.41 \mathrm{~b}$ \\
\hline & Q1303 & $1596.95 \mathrm{c}$ & - & $165.95 \mathrm{~b}$ \\
\hline & Q1304 & $1553.89 \mathrm{c}$ & $202.65 \mathrm{e}$ & $225.83 \mathrm{a}$ \\
\hline & Q1306 & $1709.18 \mathrm{c}$ & $201.45 \mathrm{e}$ & $158.52 \mathrm{~b}$ \\
\hline & Q1310 & $1688.30 \mathrm{c}$ & $310.35 \mathrm{c}$ & $195.80 \mathrm{a}$ \\
\hline & Q1317 & $1988.02 \mathrm{a}$ & $249.09 \mathrm{~d}$ & $139.13 \mathrm{~b}$ \\
\hline & Q1318 & $1504.09 \mathrm{c}$ & $466.34 \mathrm{a}$ & $149.05 \mathrm{~b}$ \\
\hline & Q1320 & $1804.33 \mathrm{~b}$ & $429.79 \mathrm{a}$ & $174.70 \mathrm{~b}$ \\
\hline & Q1321 & $1968.61 \mathrm{a}$ & - & $161.1 \mathrm{~b}$ \\
\hline & Q1324 & $1408.38 \mathrm{~d}$ & $202.56 \mathrm{e}$ & $153.07 \mathrm{~b}$ \\
\hline & Q1331 & $1272.62 \mathrm{e}$ & $245.56 \mathrm{~d}$ & $98.35 \mathrm{c}$ \\
\hline \multirow[t]{13}{*}{$\mathrm{MCR}^{3}$} & Q2014 & $1957.87 \mathrm{a}$ & $164.13 \mathrm{e}$ & - \\
\hline & Q1301 & $1810.73 \mathrm{~b}$ & $284.85 \mathrm{c}$ & - \\
\hline & Q1302 & $1217.65 \mathrm{~d}$ & $161.05 \mathrm{e}$ & - \\
\hline & Q1303 & $1691.81 \mathrm{~b}$ & $266.35 \mathrm{c}$ & - \\
\hline & Q1304 & $1634.38 \mathrm{~b}$ & $450.44 \mathrm{a}$ & - \\
\hline & Q1306 & $2027.13 \mathrm{a}$ & $227.94 \mathrm{~d}$ & - \\
\hline & Q1310 & $1408.13 \mathrm{c}$ & $337.95 \mathrm{~b}$ & - \\
\hline & Q1317 & $1518.40 \mathrm{~b}$ & $354.74 \mathrm{~b}$ & - \\
\hline & Q1318 & $1720.29 \mathrm{~b}$ & $333.35 \mathrm{~b}$ & - \\
\hline & Q1320 & $1772.15 \mathrm{~b}$ & $191.18 \mathrm{e}$ & - \\
\hline & Q1321 & $1420.53 \mathrm{c}$ & $213.13 \mathrm{~d}$ & - \\
\hline & Q1324 & $1566.94 \mathrm{~b}$ & $486.98 \mathrm{a}$ & - \\
\hline & Q1331 & $1650.30 \mathrm{~b}$ & $367.65 \mathrm{~b}$ & - \\
\hline
\end{tabular}

\footnotetext{
${ }^{1}$ The Organic Crop was in the year 2015; ${ }^{2}$ The Summer crop was in the crop year of 2014/2015 and the Winter crop was in the year 2015; ${ }^{3}$ The Summer crop was in the crop year of 2014/2015 and the Winter crop was in the year 2014; and ${ }^{4}$ Genetic values followed by the same letter belong to the same group by the Tocher test.
} 
Thus, because the average behavior of the genotypes in winter crops have a yield about one quarter of that obtained in the summer crop. This way, a selection must be made for summer cultivation and another for winter cultivation, as it is already done in crops of maize, for example, in Paraná state (Zucareli et al., 2013).

In the case of organic summer cultivation, it is worth noting that at the end of the crop cycle there was an intense attack of stink bug (Nezara viridula) on quinoa fruits, so that its yield was compromised, a condition already verified in other crops (Lourenção et al., 2010; Silva \& Sobrinho, 2017), not being different with quinoa. Two applications of Neem oil were performed as an attempt to reduce the number of stink bugs in the area, but they were not efficient. In the case of conventional cultivation, a stink bug attack was also observed, which was controlled with an application of thiamethoxam with Lambda-cyhalothrin, not significantly affecting quinoa yield. The characteristics of the plant, such as height, flowering, stand in organic crop, presented similar results to that observed in the conventional crop. The difference between these crops was during the grains filling, since the attack of stink bugs in the organic crop can not be controlled.

The genotypes Q1304 and Q1310 constitute the group a with the highest genotypic values in the organic summer crop in Entre Rios do Oeste, reaching genotypic values of 225.83 and $195.80 \mathrm{~kg} \mathrm{ha}^{-1}$, respectively (Table 3).

When we select genotypes only for their predicted genotypic values of productivity, it does not guarantee that they show superior performance when cultivated under other conditions (Cruz et al. (2014)). Due to this, we now precede the analyses of the predicted genotypic values adaptability and stability, by the method of the Harmonic mean of relative performance of genotypic values.

The genotypes Q1304, Q1310 and Q1318 formed the group with the highest values of HMGV (Table 4), indicating that they have a lower variation of the genotypic values. These three genotypes have intermediate genotypic values, thus reducing the variation of their behavior. It is noteworthy that by this method, the lower the standard deviation of the genotypic behavior between the sites of the cultivation, the greater the genotypic values harmonic mean (Resende, 2007). Therefore, the selection by the highest values of the HMGV implies simultaneous selection of stability, or even invariance of the genotypic values.

The values of RPGV*MG for the genotypes Q1304 and Q1318 evidence that they contribute to the increase of the each environment average in greater proportion, under the conditions in which they were evaluated. These two genotypes were pointed by this methodology as of great genotypic adaptability, since they have the highest values of contribution to increase the average of each experimental condition. However, when evaluating their genotypic values, they are allocated in groups $\mathrm{c}$ and $\mathrm{b}$ for the summer crops, in groups a, b and e when cultivated in the winter crop and in groups $a$ and $b$ in the organic summer crop.

The HMRPGV*MG value of the genotype Q1318 made it possible to form group a, considered to be of greater adaptability and genotypic stability by HMRPGV*MG (Resende, 2007). This genotype belonged to group b when cultivated in Marechal Cândido Rondon in the summer and winter crops, as well as when cultivated in the organic summer crop. When the genotype Q1318 was cultivated in Entre Rios do Oeste in the winter season, it was grouped in the group a with the highest genotype values, being in group $\mathrm{c}$ when the cultivation was carried out in the summer crop.

The HMRPGV*MG value of the genotype Q1304 made it possible to form group b with de genotype Q1310, considered to be high adaptability and genotypic stability by HMRPGV*MG (Table 4). These genotypes also present high genotypic adaptability and stability, thus constitutes a genetic materials of quality for cultivation.

Taking the genotypes Q1317 and Q1321 with higher genetic values in the summer crop in Entre Rios do Oeste, we found that they presented values of HMRPGV*MG grouped within groups $\mathrm{c}$ and d. For the genotypes Q1306 and Q2014, with the highest genetic values predicted for the summer crop in Marechal Cândido Rondon, we verified that their values of HMRPGV*MG are grouped in group d. Thus, it is evident that these genotypes can respond better to favorable environmental conditions, in the specific case of the summer crop cultivation.

The genotype Q1318 was the only one grouped in groups $\mathrm{a}$ and $\mathrm{b}$ when grown in the winter season in Entre Rios do Oeste or in Marechal Cândido Rondon. This genotype was also indicated as the one with the greatest genotypic adaptability and stability, thus constitutes a genetic material of quality for cultivation in the winter crop.

In order to point out one or more genotypes for organic cultivation in the summer crop we must mention the existence of the influence caused by the stink bugs that attacked the materials. In general, the plant development was satisfactory, allowing all genotypes to behave well in this crop, which was not verified due to the attack of the stink bugs, so the selection itself carries great weight relative to the attack of these insects. Therefore, the average genotypic value in organic cultivation was lower than those observed in other experiments. 
Table 4: Stability of genotypic values (HMGV), adaptability of genotypic values (RPGV*MG), stability and adaptability of genotypic values (HMRPGV*MG) for the yield trait in thirteen quinoa genotypes evaluated in five environments, in 2014/2015 agricultural year, in Marechal Cândido Rondon and Entre Rios do Oeste - Paraná, Brazil

\begin{tabular}{lccc}
\hline Genotypes & HMGV & RPGV*MG & HMRPGV*MG \\
\hline Q1014 & $317.056 \mathrm{c}$ & $808.505 \mathrm{c}$ & $732.610 \mathrm{~d}$ \\
Q1301 & $294.479 \mathrm{~d}$ & $767.804 \mathrm{e}$ & $748.933 \mathrm{~d}$ \\
Q1302 & $302.452 \mathrm{~d}$ & $711.085 \mathrm{f}$ & $661.653 \mathrm{e}$ \\
Q1303 & $363.716 \mathrm{~b}$ & $795.338 \mathrm{~d}$ & $792.915 \mathrm{c}$ \\
Q1304 & $389.466 \mathrm{a}$ & $898.510 \mathrm{a}$ & $826.805 \mathrm{~b}$ \\
Q1306 & $298.724 \mathrm{~d}$ & $762.017 \mathrm{e}$ & $728.604 \mathrm{~d}$ \\
Q1310 & $397.113 \mathrm{a}$ & $856.586 \mathrm{~b}$ & $844.262 \mathrm{~b}$ \\
Q1317 & $329.317 \mathrm{c}$ & $815.386 \mathrm{c}$ & $795.337 \mathrm{c}$ \\
Q1318 & $381.697 \mathrm{a}$ & $904.916 \mathrm{a}$ & $870.070 \mathrm{a}$ \\
Q1320 & $347.226 \mathrm{c}$ & $867.519 \mathrm{~b}$ & $809.989 \mathrm{c}$ \\
Q1321 & $330.315 \mathrm{c}$ & $765.182 \mathrm{e}$ & $739.101 \mathrm{~d}$ \\
Q1324 & $336.210 \mathrm{c}$ & $824.182 \mathrm{c}$ & $758.278 \mathrm{~d}$ \\
Q1331 & $272.452 \mathrm{e}$ & $722.080 \mathrm{f}$ & $682.017 \mathrm{e}$ \\
\hline
\end{tabular}

${ }^{1} \mathrm{HMGV}, \mathrm{RPGV} * \mathrm{MG}$ and HMRPGV*MG values followed by the same letter belong to the same group by Tocher test.

\section{CONCLUSIONS}

The genotypes Q2014, Q1306, Q1317 and Q1321 are the best indicated for cultivation in the summer crop for genetic values predicted, with yield genotypic stability and adaptability.

The genotypes Q1318, Q1304 e Q1310 are recommended for cultivation because presenting high yield genotypic stability and adaptability.

\section{ACKNOWLEDGEMENTS, FINANCIAL SUPPORT AND FULL DISCLOSURE}

This study was financed in part by the Coordenação de Aperfeiçoamento de Pessoal de Nível Superior - Brasil (CAPES) - Finance Code 001 and in party by the Fundação Araucária.

\section{REFERENCES}

Ali M, El-Sadek A \& Salem E (2018) Stability parameters and AMMI analysis of quinoa (Chenopodium quinoa Willd.). Egyptian Journal of Agronomy, 40:59-74.

Almeida Filho JE de, Tardin FD, Resende MDV de, Silva FF, Granato ÍSC \& Menezes CB de (2014) Genetic evaluation of grain sorghum hybrids in Brazilian environments using the REML/ BLUP procedure. Scientia Agricola, 71:146-150.

Bazile D, Pulvento C, Verniau A, Al-Nusairi MS, Ba D, Breidy J, Hassan L, Mohammed MI, Mambetov O, Otambekova M, Sepahvand NA, Shams A, Souici D, Miri K \& Padulosi S (2016) Worldwide evaluations of quinoa: preliminary results from post international year of quinoa FAO projects in nine countries. Frontiers in Plant Science, 07:01-18.

Colombari Filho JM, de Resende MDV, de Morais OP, de Castro AP, Guimarães ÉP, Pereira JA, Utumi MM \& Breseghello F (2013) Upland rice breeding in Brazil: A simultaneous genotypic evaluation of stability, adaptability and grain yield. Euphytica, 192:117-129
Costa AF, Leal NR, Ventura JA, Gonçalves LS, Amaral Júnior AT do \& Costa H (2015) Adaptability and stability of strawberry cultivars using a mixed model. Acta Scientiarum Agronomy, 37:435-440.

Cruz CD (2013) GENES - a software package for analysis in experimental statistics and quantitative genetics. Acta Scientiarum Agronomy, 35:271-276.

Cruz CD, Carneiro PCS \& Regazzi AJ (2014) Modelos biométricos aplicados ao melhoramento genético. $3^{\text {a }}$ ed. Viçosa, Editora UFV. 668p.

Cruz CD, Torres RAA \& Vencovsky R (1989) An alternative approach to the stability analysis proposed by Silva and Barreto. Revista Brasileira de Genética, 12:567-580.

Eberhart SA \& Russell WA (1966) Stability Parameters for Comparing Varieties. Crop Science, 06:36-40.

Freitas IL de J, do Amaral Junior AT, Viana AP, Pena GF, da Silva Cabral P, Vittorazzi C \& Silva TR da C (2013) Ganho genético avaliado com índices de seleção e com REML/Blup em milhopipoca. Pesquisa Agropecuária Brasileira, 48:1464-1471.

Gauch HG (2006) Statistical Analysis of Yield Trials by AMMI and GGE. Crop Science, 46:1488-1500.

Hawerroth MC, Carvalho FIF de, Oliveira AC De, Silva JAG da, Gutkoski LC, Sartori JF, Woyann LG, Barbieri RL \& Hawerroth FJ (2013) Adaptability and stability of white oat cultivars in relation to chemical composition of the caryopsis. Pesquisa Agropecuária Brasileira, 48:42-50.

Lourenção AL, Reco PC, Braga NR, Valle GE do \& Pinheiro JB (2010) Produtividade de genótipos de soja sob infestação da lagarta-da-soja e de percevejos. Neotropical Entomology, 39:275-281

Oliveira IJ de, Atroch AL, Dias MC, Guimarães LJ \& Guimarães PE de O (2017) Selection of corn cultivars for yield, stability, and adaptability in the state of Amazonas, Brazil. Pesquisa Agropecuária Brasileira, 52:455-463.

Pupin S, Santos VAA, Zaruma UGD, Miranda CA, Silva HMP, Marinho LC, Sebbenn MA \& Moraes MLT (2015) Produtividade, estabilidade e adaptabilidade em progênies de polinização aberta de Eucalyptus urophylla S.T. Blake. Scientia Forestalis, 43:127-134. 
Resende MDV (2002) Genética biométrica e estatística no melhoramento de plantas perenes. $1^{a}$ ed. Brasília, Embrapa Informação Tecnológica. 975 p.

Resende MDV de (2007) Matemática e estatística na análise de experimentos e no melhoramento genético. $1^{\mathrm{a}}$ ed. Colombo, Embrapa Florestas. 362p.

Resende MDV de (2016) Software Selegen-REML / BLUP/ : a useful tool for plant breeding. Crop Breeding and Applied Biotechnology, 16:330-339.

Rodrigues EV, Teodoro PE, Peixoto LA, Silva LA, Laviola BG \& Bhering LL (2017) Selection of Jatropha full-sib families based on genotypic adaptability and stability via mixed models. Genetics and Molecular Research, 16:01-10.

Silva PH \& Sobrinho CA (2017) Níveis de dano e de controle do percevejo-verde-da-soja Nezara viridula (Hemiptera: Pentatomidae) em feijão-caupi. Revista Agro@mbiente, 11:373378

Silva GO da, de Carvalho ADF, Vieira JV \& Benin G (2011) Verificação da adaptabilidade e estabilidade de populações de cenoura pelos métodos AMMI, GGE biplot e REML/BLUP. Bragantia, 70:494-501.

Spehar CR \& Rocha JE da S (2010) Exploiting genotypic variability from low-altitude Brazilian Savannah-adapted Chenopodium quinoa. Euphytica, 175:13-21.

Spehar CR, Rocha JE da S \& Santos RL de B (2011) Desempenho Agronomico e recomendações para cultivo de quinoa (BRS Syetetuba) no cerrado. Pesquisa Agropecuária Tropical, 41:145147
Tardieu F (2013) Plant response to environmental conditions: Assessing potential production, water demand, and negative effects of water deficit. Frontiers in Physiology, 04:01-11.

Torres FE, Teodoro PE, Sagrilo E, Ceccon G \& Correa AM (2015) Interação genótipo $\mathrm{x}$ ambiente em genótipos de feijão-caupi semiprostrado via modelos mistos. Bragantia, 74:255-260.

Torres Filho J, dos Santos Oliveira CN, da Silveira LM, de Sousa Nunes GH, da Silva AJ \& da Silva MF (2017) Genotype By environment interaction in green cowpea analyzed Via mixed Models. Revista Caatinga, 30:687-697.

Vasconcelos ES De, Egewarth JF, Oliveira GA \& Piano JT (2013) Características agronômicas de genótipos de quinoa. Scientia Agraria Paranaensis, 12:371-376.

Vasconcelos ES de, Reis MS, Cruz CD, Sediyama T \& Scapim CA (2011) Integrated method for adaptability and phenotypic stability analysis. Acta Scientiarum Agronomy, 33:251-257.

Vasconcelos ES De, Reis MS, Cruz CD, Sediyama T \& Scapim CA (2010) Adaptability and stability of semilate and late maturing soybean genotypes in Minas Gerais state. Acta Scientiarum Agronomy, 32:411-415.

Zucareli C, Oliveira MA, Spolaor LT \& Ferreira AS (2013) Desempenho Agronômico de genótipos de milho de segunda safra na região Norte do Paraná. Scientia Agraria Paranaensis, 12:227235 .

Zurita-Silva A, Fuentes F, Zamora P, Jacobsen SE \& Schwember AR (2014) Breeding quinoa (Chenopodium quinoa Willd.): Potential and perspectives. Molecular Breeding, 34:13-30. 